\title{
Evaluation and Challenges of Research Groups in Higher Education: A Study in Faculty of Mathematics and Natural Sciences, Sebelas Maret University
}

\author{
Ahmad Ainurofiq \\ Sebelas Maret University
}

This article presents evaluations and challenges in managing Research Groups in Higher Education: Studies at the Mathematics and Natural Sciences Faculty, Sebelas Maret University (FMIPA UNS). Data were collected by an online survey conducted on FMIPA UNS lecturers included in the research group by filling a survey. The survey questions include 44 items classified into four groups, i.e. strength, weakness, opportunity, and threat. The questions were measured using the 5-point Likert scale. The obtained survey data were assessed using the Strengths, Weakness, Oppotunities and Threats (SWOT) analysis. SWOT analysis was conducted by determining the position of the quadrants. Analysis result was in the second quadrant, which showed that the research group required a diversification strategy to grow. These data could provide information on the management needed. There should be a policy on the performance improvement of the research group, and the obtained data could aid in making a decision and changing management to be used for further investigations.

Keywords: research group, Faculty of Mathematics and Natural Sciences, Sebelas Maret University, SWOT analysis, higher education

\section{INTRODUCTION}

The performance results of the UNS research and community service (P2M) under the management of LPPM UNS developed rapidly. Based on the clustering made by the Ministry of Research, Technology, and High Education, UNS is categorized as independent in research and superior in community service. This success cannot be separated from the internal management system of P2M UNS. To achieve the Key Performance Indicator (KPI) of UNS, LPPM created research groups as the cutting edge of P2M activity to obtain the increased achievement of the involvement of researchers and devotees in various schemes of P2M and increased publication outcome achievement as targeted by the KPI. The research group is a strategy to increase the quality and quantity of P2M. The formation of the research group had several benefits, include: as an analysis of the lecturer resource power in UNS, reinforcement of UNS strategic synergy as an impact of research and community service on the quality of teaching and reinforcement of innovation growth, increased lecturer participation, reinforcement of academic integration, and determination of development scope and strategic research innovation target, identification of research power, display of research collaboration, analysis of research trend, and identification of lecturer expertise in UNS, and a more focused research development strategies (LPPM UNS, 2020). The Faculty Coordinator of Research and Community Service (KPPMF) has an important role to guarantee the implementation of 
P2M. The development of a research group coordinated by KPPMF is expected to lead to the fusion of unidirectional scientific studies in the process of innovation. Therefore, research groups can grow with their characteristic superiority to produce research products in the form of publications or quality innovative products. These survey data are beneficial as information in learning about strength, weakness, opportunity, and threat patterns in the research group. The analyzed data provided the most important criteria for the development of a research group, which can be used for intervention strategies to improve the performance of a research group and develop a more adaptive policy. This information is beneficial for all related parties, especially researchers, practicians, university management, ministry of higher education, or state authorities in the development of research climate and management of a research group. These data can be used by other researchers to find a model for the performance evaluation of a research group in different universities. This instrument can be used as an adapted platform for similar studies by other researchers.

\section{MATERIALS AND METHODS}

The data for this study were obtained through the survey using structured and validated questions with items adjusted to conditions in the research group. Samples were taken by filling in survey forms during September 2020. Data were collected using online questions through the provided link. Samples were specific for FMIPA UNS lecturers included in a research group. For data collection, 44 participants from 141 FMIPA UNS lecturers included in research groups from 8 study programs filled the survey. The total participants represented all research groups in FMIPA, which consisted of 30 as shown in Table 1. Each participant provided consent to fill the only survey directly. The identity of the participants was maintained but kept secret by the authors to determine that the participant is in a research group. The sampling technique was done randomly from the lecturer population to represent each research group and study program. There should not be a "mysterious" participant filling the survey. Therefore, participants must include their identity and the name of their research group. If the data input was incompatible with the system, then the data would not be included in the analysis.

The participants choose to agree with the statements and instruments used. The questionnaire was measured with a 5-point Likert scale. There are 5-point choices of the Likert scale based on the appointed typicality (Bowling and Hammond, 2008). The answers for the scale was designed with five choices, i.e. 1 (Strongly Disagree), 2 (Disagree), 3 (Uncertain), 4 (Agree), and 5 (Strongly Agree) (Mulyono and Saskia, 2020). The question system was assessed using the SWOT analysis, i.e. strength, weakness, opportunity, and threat. The questions included 44 items classified into four groups, consisted of 16 strength questions, 14 weaknesses, 6 opportunities, and 8 threats. Each SWOT group had the same total weight of 1 even though they have a different number of items. The weight of 1 was divided by the number of questions. Therefore, the weight of each item in one group is the same. The SWOT analysis model adopted the pattern from LPPM UNS as the parent of the research group. Although, the components of statements used in this SWOT analysis are a different design from LPPM UNS (LPPM UNS, 2020). The SWOT analysis was conducted by determining the quadrant position (Fardani et al., 2020). Certain quadrants can describe the condition of the research group during the survey. Based on the SWOT analysis results, the authors provided a solution of measures to improve the performance of the research group (Forleo and Palmieri, 2019; Kolomiets et al., 2019).

\section{RESULTS AND DISCUSSION}

The provided data consisted of information on the performance of the FMIPA UNS research group in 2020. Data were obtained according to the SWOT analysis to explore the strength, weaknesses, opportunities, and threats of the research group (Kaushik, 2018). The participants were FMIPA UNS

lecturers, who consisted of 44 people, i.e. $31.2 \%$ of the total lecturer population in FMIPA UNS of 141 people. The participants were representative because they were spread in 8 study programs (Mathematics, Physics, Chemistry, Biology, Informatics, Pharmacy, Statistics, and Environmental Science) and were 
included in 30 research groups presented in Table 1. Table 1 lists the research groups in FMIPA UNS in 2020-2021 based on the Dean's Decree.

TABLE 1

LIST OF RESEARCH GROUPS IN FMIPA UNS IN 2020-2021

\begin{tabular}{|l|l|l|}
\hline NO & RESEARCH GROUPS & STUDY PROGRAMS \\
\hline $\mathbf{1}$ & Combinatorial Mathematics & Mathematics \\
\hline $\mathbf{2}$ & Mathematical Soft Computing & Mathematics \\
\hline $\mathbf{3}$ & Pure Mathematics and Application & Mathematics \\
\hline $\mathbf{4}$ & Applied and Mathematical Analysis & Mathematics \\
\hline $\mathbf{5}$ & Magnetic Sensor and Materials & Physics \\
\hline $\mathbf{6}$ & Optics and Photonics & Physics \\
\hline $\mathbf{7}$ & Electronic Materials and Energy & Physics \\
\hline $\mathbf{8}$ & Advanced Materials & Physics \\
\hline $\mathbf{9}$ & Theoritical and Computational Physics & Physics \\
\hline $\mathbf{1 0}$ & Accoustics and Geophysics & Physics \\
\hline $\mathbf{1 1}$ & Electronics and Instrumentation & Physics \\
\hline $\mathbf{1 2}$ & Natural Products and Synthetic Organic Chemistry & Chemistry \\
\hline $\mathbf{1 3}$ & Solid State Chemistry and Catalysis & Chemistry \\
\hline $\mathbf{1 4}$ & Inorganic Materials & Chemistry \\
\hline $\mathbf{1 5}$ & Analytical and Environmental Chemistry & Chemistry \\
\hline $\mathbf{1 6}$ & Plasma Science and Technology & Chemistry \\
\hline $\mathbf{1 7}$ & Animal Biomaterials & Biology \\
\hline $\mathbf{1 8}$ & Plant Biomaterials & Biology \\
\hline $\mathbf{1 9}$ & Microbial Biomaterials & Biology \\
\hline $\mathbf{2 0}$ & Biodiversity & Biology \\
\hline $\mathbf{2 1}$ & Intelligence Systems and Humanized Computing (ISHC) & Informatics \\
\hline $\mathbf{2 2}$ & Computational Science and Engineering (CSE) & Informatics \\
\hline $\mathbf{2 3}$ & Data, Information and Knowledge Engineering (DIKE) & Informatics \\
\hline $\mathbf{2 4}$ & Computer Networks and Security (CNS) & Informatics \\
\hline $\mathbf{2 5}$ & Active Pharmaceutical Discovery and Development (APDD) & Pharmacy \\
\hline $\mathbf{2 6}$ & Metabolic Disorders & Pharmacy \\
\hline $\mathbf{2 7}$ & Statistics and Data Science in Industry and Economics & Statistics \\
\hline $\mathbf{2 8}$ & Statistics and Data Science in Environmental and Health & Statistics \\
\hline $\mathbf{2 9}$ & Environment And Climate Change & Environmental Science \\
\hline $\mathbf{3 0}$ & Ecology & Environmental Science \\
\hline
\end{tabular}

The information in Table 2 represented a group of SWOT analysis questions with the characteristics of responses and the number of participants' percentage based on the Likert scale. The participants received adequate and correct information and questions on their research group condition. The composition of the questions varies considerably, such as the role of the research group, facilities, agenda, funding, the track record of achievement, management, and teamwork. The participants were given chances and freedom to choose and provide their opinions and their confidentiality is maintained. The participants answered the survey according to the condition of each research group based on the 5-point Likert scale lists to measure each research group. It should be noted that the chosen 5-point Likert scale is a representation of the participants' view on the research group, which affects the future development of the research group. Interpretation of the responses can provide a clear understanding of the participants' composition and can 
be used for policymaking from the authorities in the Faculty of the University to improve the performance and effectiveness of research and community service and for further studies (Zhu and Mugenyi, 2015).

TABLE 2

COMPONENTS OF SWOT QUESTIONS AND PERCENTAGE OF PARTICIPANTS

\begin{tabular}{|c|c|c|c|c|c|c|}
\hline \multirow[t]{2}{*}{ No } & \multirow{2}{*}{$\begin{array}{l}\text { Item components of Strength (S), } \\
\text { Weakness }(\mathrm{W}) \text {, Opportunities }(\mathrm{O}), \\
\text { and Threats }(\mathrm{T})\end{array}$} & \multicolumn{5}{|c|}{ \% of participants with Likert Scale: } \\
\hline & & $\begin{array}{l}\text { Strongly } \\
\text { disagree }\end{array}$ & Disagree & Uncertain & Agree & $\begin{array}{l}\text { Strongly } \\
\text { Agree }\end{array}$ \\
\hline S1 & $\begin{array}{l}\text { The position of the research group is } \\
\text { strong and strategic because there is a } \\
\text { UNS Rector Regulation on the } \\
\text { Implementation of Research Group- } \\
\text { based Research and Community } \\
\text { Service (P2M). }\end{array}$ & 0 & 4,5 & 15,9 & 52,3 & 27,3 \\
\hline S2 & $\begin{array}{l}\text { The research group is the cutting edge } \\
\text { of innovation in } \mathrm{P} 2 \mathrm{M} \text { as a more } \\
\text { focused research development with } \\
\text { characteristic superiority. }\end{array}$ & 0 & 2,3 & 25 & 36,4 & 36,4 \\
\hline $\mathbf{S 3}$ & $\begin{array}{l}\text { The research group has a clear } \\
\text { objective and job description. }\end{array}$ & 0 & 2,3 & 22,7 & 47,7 & 27,3 \\
\hline S4 & $\begin{array}{l}\text { The research group has a structured } \\
\text { and directed roadmap to improve the } \\
\text { performance effectivity referring to the } \\
13 \text { (thirteen) themes of UNS research } \\
\text { in line with Rencana Induk Riset } \\
\text { Nasional (RIRN) 2017-2045 and } \\
\text { Prioritas Riset Nasional (PRN) 2020- } \\
2024 \text { (Permenristekdikti, 2019). }\end{array}$ & 0 & 4,5 & 22,7 & 47,7 & 25 \\
\hline S5 & $\begin{array}{l}\text { The operational standard of the } \\
\text { implementation of Research Group, } \\
\text { P2M planning, and mechanism of } \\
\text { performance measurement of a } \\
\text { Research Group is described in the } \\
\text { P2M Guide Funded from PNBP UNS. }\end{array}$ & 0 & 2,3 & 29,5 & 56,8 & 11,4 \\
\hline S6 & $\begin{array}{l}\text { The management of Research Group } \\
\text { membership is well structured and } \\
\text { based on the regulation on the number } \\
\text { of members, requirement of members, } \\
\text { requirement for Research Group } \\
\text { leader, and regulation on P2M } \\
\text { proposal submission through the } \\
\text { research group. }\end{array}$ & 0 & 4,5 & 22,7 & 59,1 & 13,6 \\
\hline S7 & $\begin{array}{l}\text { The tiered coaching scheme started } \\
\text { from becoming a researcher, entering } \\
\text { the research group, center of } \\
\text { study/center of research, to UNS } \\
\text { center of excellence/Ipteks is a design } \\
\text { to support achieving P2M performers. }\end{array}$ & 2,3 & 9,1 & 15,9 & 54,5 & 18,2 \\
\hline
\end{tabular}




\begin{tabular}{|c|c|c|c|c|c|c|}
\hline S8 & $\begin{array}{l}\text { The suitable theme for } \\
\text { researchers/devotees in achieving P2M } \\
\text { grant according to the Research Group } \\
\text { roadmap supported by various P2M } \\
\text { schemes and appropriate funding is a } \\
\text { strategy to improve the performance of } \\
\text { UNS P2M. }\end{array}$ & 0 & 0 & 20,5 & 56,8 & 22,7 \\
\hline S9 & $\begin{array}{l}\text { The research group development } \\
\text { agenda is well-organized (research, } \\
\text { service, publication, } \\
\text { seminar/conference, workshop, } \\
\text { training/short course, overseas visit } \\
\text { plans of visiting scholar/researcher). }\end{array}$ & 0 & 9,1 & 29,5 & 52,3 & 9,1 \\
\hline S10 & $\begin{array}{l}\text { Track record of P2M achievements } \\
\text { from the research group is good and } \\
\text { documented (competitive research, } \\
\text { publication in scientific journals, } \\
\text { publication in proceedings, the } \\
\text { achievement of Intellectual Property } \\
\text { Rights/patent and technological } \\
\text { creations, book chapters, publication in } \\
\text { magazines or the mass media). }\end{array}$ & 2,3 & 2,3 & 25 & 54,5 & 15,9 \\
\hline S11 & $\begin{array}{l}\text { The research group has a high } \\
\text { achievement of funding for research } \\
\text { and community service from outside } \\
\text { the university (domestic and foreign). }\end{array}$ & 0 & 22,7 & 29,5 & 40,9 & 6,8 \\
\hline S12 & $\begin{array}{l}\text { The research group has a high } \\
\text { publication spirit and good publication } \\
\text { quality by choosing quality } \\
\text { journals/proceedings by following } \\
\text { indexing agencies such as } \\
\text { Scopus/WOS. }\end{array}$ & 0 & 4,5 & 20,5 & 50 & 25 \\
\hline S13 & $\begin{array}{l}\text { The research and community service } \\
\text { achievement by the research group has } \\
\text { reached a certain Technology } \\
\text { Readiness Level (TRL) with the } \\
\text { potential to be developed into a } \\
\text { business unit (Permenristekdikti, 2016) }\end{array}$ & 2,3 & 6,8 & 45,5 & 36,4 & 9,1 \\
\hline S14 & $\begin{array}{l}\text { Good coordination and teamwork } \\
\text { between members in a research group } \\
\text { (in the aspect of research, service, and } \\
\text { scientific publication). }\end{array}$ & 0 & 6,8 & 18,2 & 50 & 25 \\
\hline S15 & $\begin{array}{l}\text { Research group members are skillful } \\
\text { and have a synergistic field of studies } \\
\text { to obtain a quality research group. }\end{array}$ & 0 & 2,3 & 15,9 & 50 & 31,8 \\
\hline S16 & $\begin{array}{l}\text { The management of } \mathrm{P} 2 \mathrm{M} \\
\text { administration and information system } \\
\text { for the research group is supported by }\end{array}$ & 0 & 11,4 & 20,5 & 54,5 & 13,6 \\
\hline
\end{tabular}




\begin{tabular}{|c|c|c|c|c|c|c|}
\hline & $\begin{array}{l}\text { adequate information technology and } \\
\text { computerization. }\end{array}$ & & & & & \\
\hline W1 & $\begin{array}{l}\text { Lecturer participation in research and } \\
\text { community service is still uneven. } \\
\text { Therefore, the productivity, process } \\
\text { quality, and outcome of P2M are not } \\
\text { optimal. }\end{array}$ & 4,5 & 20,5 & 29,5 & 38,6 & 6,8 \\
\hline W2 & $\begin{array}{l}\text { The ability of the research group in } \\
\text { obtaining competitive research funding } \\
\text { from outside the university by various } \\
\text { national and international donor } \\
\text { institutions is limited. }\end{array}$ & 2,3 & 9,1 & 29,5 & 54,5 & 4,5 \\
\hline W3 & $\begin{array}{l}\text { There is a lack of ability of the } \\
\text { research group to collaborate or joint } \\
\text { research with researchers from other } \\
\text { universities, both in and outside the } \\
\text { country. }\end{array}$ & 2,3 & 6,8 & 31,8 & 45,5 & 13,6 \\
\hline W4 & $\begin{array}{l}\text { There is a lack of teamwork in the } \\
\text { research group to work together, grow, } \\
\text { and develop together and provide a } \\
\text { higher impact. }\end{array}$ & 4,5 & 13,6 & 45,5 & 31,8 & 4,5 \\
\hline W5 & $\begin{array}{l}\text { The enforcement of Dean's Decree } \\
\text { concerning the formation of a } \\
\text { Research Group that is valid for two } \\
\text { years leads to a limited duration of } \\
\text { performance continuation of the } \\
\text { research group. }\end{array}$ & 4,5 & 13,6 & 43,2 & 29,5 & 9,1 \\
\hline W6 & $\begin{array}{l}\text { Low desire from the researchers in the } \\
\text { research group to improve self- } \\
\text { capacity. }\end{array}$ & 11,4 & 29,5 & 43,2 & 15,9 & 0 \\
\hline W7 & $\begin{array}{l}\text { The research group did not represent } \\
\text { the group of lecturers with } \\
\text { unidirectional scientific studies. } \\
\text { Therefore, an ideal research group is } \\
\text { not yet formed, and a more focused } \\
\text { research development target is not } \\
\text { achieved. }\end{array}$ & 4,5 & 18,2 & 43,2 & 25 & 9,1 \\
\hline W8 & $\begin{array}{l}\text { The research group has not been } \\
\text { effective in improving overall } \mathrm{P} 2 \mathrm{M} \\
\text { performance and publication, proven } \\
\text { by uneven Research Group } \\
\text { performance index with the majority } \\
\text { of low. The role of personal fighters in } \\
\text { the implementation of P2M in the } \\
\text { research group is still high. }\end{array}$ & 4,5 & 22,7 & 31,8 & 31,8 & 9,1 \\
\hline W9 & $\begin{array}{l}\text { Lower publication growth in FMIPA } \\
\text { research group compared to research } \\
\text { groups in other faculties in UNS and } \\
\text { other universities. }\end{array}$ & 9,1 & 31,8 & 40,9 & 15,9 & 2,3 \\
\hline
\end{tabular}




\begin{tabular}{|c|c|c|c|c|c|c|}
\hline W10 & $\begin{array}{l}\text { Lack of certified research-specialized } \\
\text { laboratory facilities as research support } \\
\text { facilities and services for the research } \\
\text { group. }\end{array}$ & 2,3 & 11,4 & 22,7 & 27,3 & 36,4 \\
\hline W11 & $\begin{array}{l}\text { Low quality of books, e-books, } \\
\text { journals, and e-journals library } \\
\text { collection for research support } \\
\text { facilities and services for the research } \\
\text { group. }\end{array}$ & 9,1 & 25 & 34,1 & 20,5 & 11,4 \\
\hline W12 & $\begin{array}{l}\text { The database integration on personal } \\
\text { or research group achievement } \\
\text { (activities of university tri dharma) in } \\
\text { MIPA is still lacking. }\end{array}$ & 0 & 11,4 & 43,2 & 31,8 & 13,6 \\
\hline W13 & $\begin{array}{l}\text { Low awareness to report } \mathrm{P} 2 \mathrm{M} \\
\text { teamwork activities of the research } \\
\text { group with external parties. }\end{array}$ & 2,3 & 11,4 & 50 & 25 & 11,4 \\
\hline W14 & $\begin{array}{l}\text { The process of proposal submission } \\
\text { for P2M grant from lecturers as a } \\
\text { research group member is relatively } \\
\text { difficult. }\end{array}$ & 13,6 & 22,7 & 34,1 & 25 & 4,5 \\
\hline 01 & $\begin{array}{l}\text { There are research grant/funding offers } \\
\text { from various parties local, national, } \\
\text { and international. }\end{array}$ & 0 & 2,3 & 31,8 & 45,5 & 20,5 \\
\hline $\mathbf{O 2}$ & $\begin{array}{l}\text { The possibility of cooperative network } \\
\text { development with research and } \\
\text { community service partners and } \\
\text { international seminar holdings from } \\
\text { various parties local, national, and } \\
\text { international. }\end{array}$ & 0 & 2,3 & 20,5 & 59,1 & 18,2 \\
\hline $\mathbf{O 3}$ & $\begin{array}{l}\text { There is a network system, technology, } \\
\text { information, and communication, } \\
\text { especially through open-source } \\
\text { platforms. }\end{array}$ & 0 & 2,3 & 38,6 & 50 & 9,1 \\
\hline O4 & $\begin{array}{l}\text { Many chances for standardization, } \\
\text { accreditation, and certification } \\
\text { (acknowledgment). }\end{array}$ & 2,3 & 11,4 & 29,5 & 50 & 6,8 \\
\hline 05 & $\begin{array}{l}\text { There are various publication media on } \\
\text { many levels (regional-national- } \\
\text { international). }\end{array}$ & 0 & 6,8 & 11,4 & 50 & 31,8 \\
\hline O6 & $\begin{array}{l}\text { Many possibilities of cooperation and } \\
\text { collaboration with industries, } \\
\text { government, overseas universities, and } \\
\text { overseas institutions. }\end{array}$ & 2,3 & 9,1 & 25 & 50 & 13,6 \\
\hline T1 & $\begin{array}{l}\text { Demands of research outcome for the } \\
\text { research group on articles published in } \\
\text { accredited national journals, Scopus- } \\
\text { indexed international journals, Scopus- } \\
\text { indexed proceedings, textbooks, and } \\
\text { book chapters. }\end{array}$ & 0 & 9,1 & 34,1 & 43,2 & 13,6 \\
\hline
\end{tabular}




\begin{tabular}{|l|l|l|l|l|l|l|}
\hline T2 & $\begin{array}{l}\text { Demands of lecturer quality and } \\
\text { quantity for article publications in } \\
\text { Scopus-indexed international journals. }\end{array}$ & 0 & 4,5 & 25 & 45,5 & 25 \\
\hline T3 & $\begin{array}{l}\text { Demands lecturer reinforcement and a } \\
\text { broadminded research group with an } \\
\text { international reputation. }\end{array}$ & 0 & 2,3 & 27,3 & 47,7 & 22,7 \\
\hline T4 & $\begin{array}{l}\text { The need for adequate and certified } \\
\text { research-specialized laboratory } \\
\text { capacity. }\end{array}$ & 0 & 4,5 & 20,5 & 34,1 & 40,9 \\
\hline T5 & $\begin{array}{l}\text { The need for quality books, e-books, } \\
\text { journals, and e-journals library } \\
\text { collection for reference sources. }\end{array}$ & 2,3 & 0 & 15,9 & 38,6 & 43,2 \\
\hline T6 & $\begin{array}{l}\text { Demands of standardization needs, } \\
\text { such as SNI, ASTM, JIS, ISO, etc. }\end{array}$ & 0 & 0 & 29,5 & 45,5 & 25 \\
\hline T7 & $\begin{array}{l}\text { High demands of outcome quality and } \\
\text { commercialization of research results } \\
\text { and services. }\end{array}$ & 0 & 4,5 & 31,8 & 47,7 & 15,9 \\
\hline T8 & $\begin{array}{l}\text { Demands good institutional } \\
\text { management and governance. }\end{array}$ & 0 & 0 & 20,5 & 52,3 & 27,3 \\
\hline
\end{tabular}

The process of SWOT analysis results is shown in Table 3. The SWOT analysis results showed several points that needed more attention due to higher or lower Likert scale scores compared to other questions. For example, item S11 from the strength component had the lowest score compared to other items. For the solution, the research group should increase research and community service funding from outside the University, both from within and outside the country. The highest weakness component was W10. Therefore, there should be a research-specialized laboratory facility. Meanwhile, the highest threat was T5, which was the need for a library for books, e-books, journals, and e-journals collection as quality reference sources. Analysis data could aid the management of Faculty and University in considering the priority scale of measures taken in determining policy and decisions which help position the university within the world (Longhurst et al., 2020).

TABLE 3

SWOT ANALYSIS RESULTS OF THE RESEARCH GROUP

\begin{tabular}{lllll}
\hline SWOT & Total Likert Scale Score & Mean Score & Weight & Value \\
\hline S1 & 177 & 4.023 & 0.0625 & 0.251 \\
S2 & 179 & 4.068 & 0.0625 & 0.254 \\
S3 & 176 & 4.000 & 0.0625 & 0.250 \\
S4 & 173 & 3.932 & 0.0625 & 0.246 \\
S5 & 166 & 3.773 & 0.0625 & 0.236 \\
S6 & 168 & 3.818 & 0.0625 & 0.239 \\
S7 & 166 & 3.773 & 0.0625 & 0.236 \\
S8 & 177 & 4.023 & 0.0625 & 0.251 \\
S9 & 159 & 3.614 & 0.0625 & 0.226 \\
S10 & 167 & 3.795 & 0.0625 & 0.237 \\
S11 & 146 & 3.318 & 0.0625 & 0.207 \\
S12 & 174 & 3.955 & 0.0625 & 0.247 \\
S13 & 151 & 3.432 & 0.0625 & 0.214 \\
S14 & 173 & 3.932 & 0.0625 & 0.246 \\
S15 & 181 & 4.114 & 0.0625 & 0.257 \\
\hline
\end{tabular}




\begin{tabular}{lllll}
\hline S16 & 163 & 3.705 & 0.0625 & 0.232 \\
TOTAL & & & 1 & 3.830 \\
W1 & 142 & 3.227 & 0.0714 & 0.231 \\
W2 & 154 & 3.500 & 0.0714 & 0.250 \\
W3 & 159 & 3.614 & 0.0714 & 0.258 \\
W4 & 140 & 3.182 & 0.0714 & 0.227 \\
W5 & 143 & 3.250 & 0.0714 & 0.232 \\
W6 & 116 & 2.636 & 0.0714 & 0.188 \\
W7 & 139 & 3.159 & 0.0714 & 0.226 \\
W8 & 140 & 3.182 & 0.0714 & 0.227 \\
W9 & 119 & 2.705 & 0.0714 & 0.193 \\
W10 & 169 & 3.841 & 0.0714 & 0.274 \\
W11 & 132 & 3.000 & 0.0714 & 0.214 \\
W12 & 153 & 3.477 & 0.0714 & 0.248 \\
W13 & 146 & 3.318 & 0.0714 & 0.237 \\
W14 & 125 & 2.841 & 0.0714 & 0.203 \\
TOTAL & & & 1 & 3.209 \\
O1 & 169 & 3.841 & 0.1667 & 0.640 \\
O2 & 173 & 3.932 & 0.1667 & 0.655 \\
O3 & 161 & 3.659 & 0.1667 & 0.610 \\
O4 & 153 & 3.477 & 0.1667 & 0.580 \\
O5 & 179 & 4.068 & 0.1667 & 0.678 \\
O6 & 160 & 3.636 & 0.1667 & 0.606 \\
TOTAL & & & 1 & 3.769 \\
T1 & 159 & 3.614 & 0.125 & 0.452 \\
T2 & 172 & 3.909 & 0.125 & 0.489 \\
T3 & 172 & 3.909 & 0.125 & 0.489 \\
T4 & 181 & 4.114 & 0.125 & 0.514 \\
T5 & 185 & 4.205 & 0.125 & 0.494 \\
T6 & 174 & 3.955 & 0.125 & 0.569 \\
T7 & 165 & 3.750 & 0.125 & 3.940 \\
T8 & 179 & 4.068 & 0.125 & \\
TOTAL & & & 1 & \\
\hline & & & & \\
\hline
\end{tabular}

SWOT analysis is used to determine the strength of correlation and results from the observed effects. The calculation results showed $\mathrm{S}=3.830, \mathrm{~W}=3.20, \mathrm{O}=3.769$, and $\mathrm{T}=3.940$. This value was in the second quadrant $(+,-)$, which was $(0.62,-0,17)$. General research group condition mapping can be seen in Figure 1 , which showed the research group position in a quadrant 2 graphic, which means a diversification strategy is needed. This analysis could provide different insights on what to manage. This requires commitment from all research group members to improve their task responsibilities, especially in a highly competitive $\mathrm{P} 2 \mathrm{M}$ field. 
FIGURE 1

THE QUADRANT POSITION OF SWOT ANALYSIS FROM THE RESEARCH GROUP

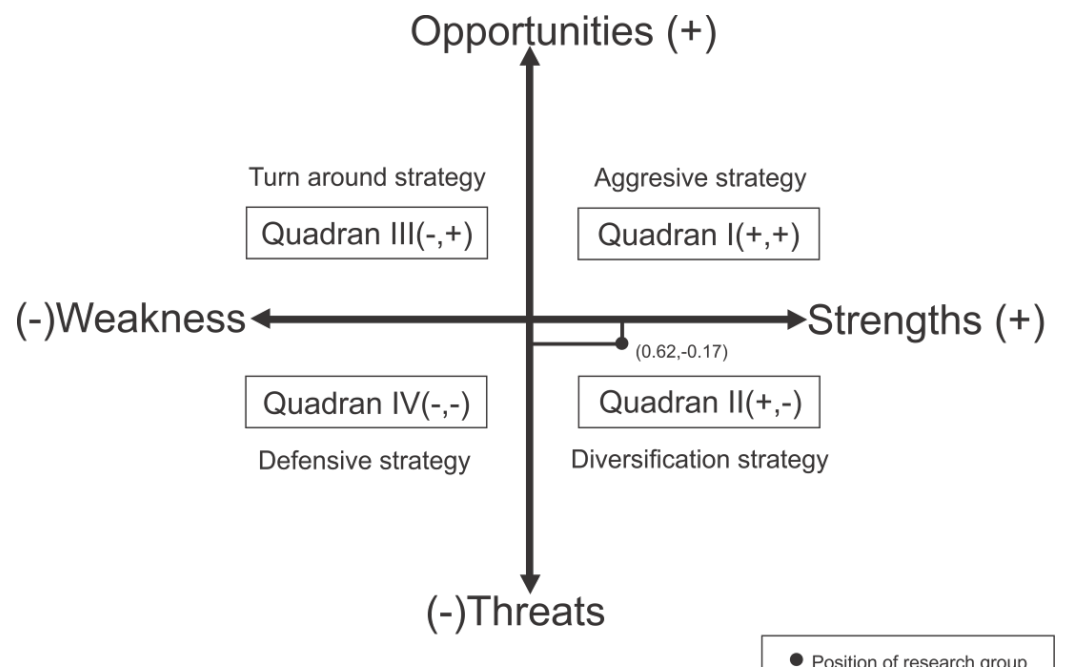

The correlation of the SWOT analysis results provides a solution of efforts in improving the performance of the research group using mapping as shown in Table 4, which showed an interactive matrix and SWOT strategy alternatives. The proposed improvements from the SWOT data analysis will help determine the prediction level of each construction which supports a more effective performance.

TABLE 4

\section{INTERACTION MATRIX AND SWOT STRATEGY ALTERNATIVE}

\begin{tabular}{|c|c|c|}
\hline $\begin{array}{l}\text { INTERNAL } \\
\text { FACTOR } \\
\text { EXTERNAL } \\
\text { FACTOR }\end{array}$ & STRENGTH (S) & WEAKNESS (W) \\
\hline $\begin{array}{l}\text { OPPORTUNITY } \\
\text { (O) }\end{array}$ & $\begin{array}{ll}\text { S-O } & \\
\text { - Improvement of quality and } \\
\text { quantity of publication by } \\
\text { choosing and utilizing quality } \\
\text { journals/proceedings. } \\
\text { - Improvement of cooperation } \\
\text { network with research and } \\
\text { community service partners. } \\
\text { - Improvement of international } \\
\text { seminar holdings. } \\
\text { Integration of group research } \\
\text { data with units and } \\
\text { institutions concerning P2M } \\
\text { activity achievements. } \\
\text { Improvement of researchers } \\
\text { and devotees' ability in } \\
\text { compiling research/service } \\
\text { activity roadmap related to } \\
\text { funding. }\end{array}$ & $\begin{array}{ll}\text { W-O } & \\
\text { - Improvement of the capability } \\
\text { to obtain research and service } \\
\text { funding/grants from various } \\
\text { parties (within and outside the } \\
\text { country). } \\
\text { - Improvement of coordination } \\
\text { and synergy within the research } \\
\text { group and with many parties. } \\
\text { - Improvement of the network } \\
\text { system, technology, } \\
\text { information, communication, } \\
\text { and database integration. } \\
\text { Perform standardization and } \\
\text { process control of the programs } \\
\text { and activities within the } \\
\text { research group to fulfill quality } \\
\text { assurance. }\end{array}$ \\
\hline
\end{tabular}




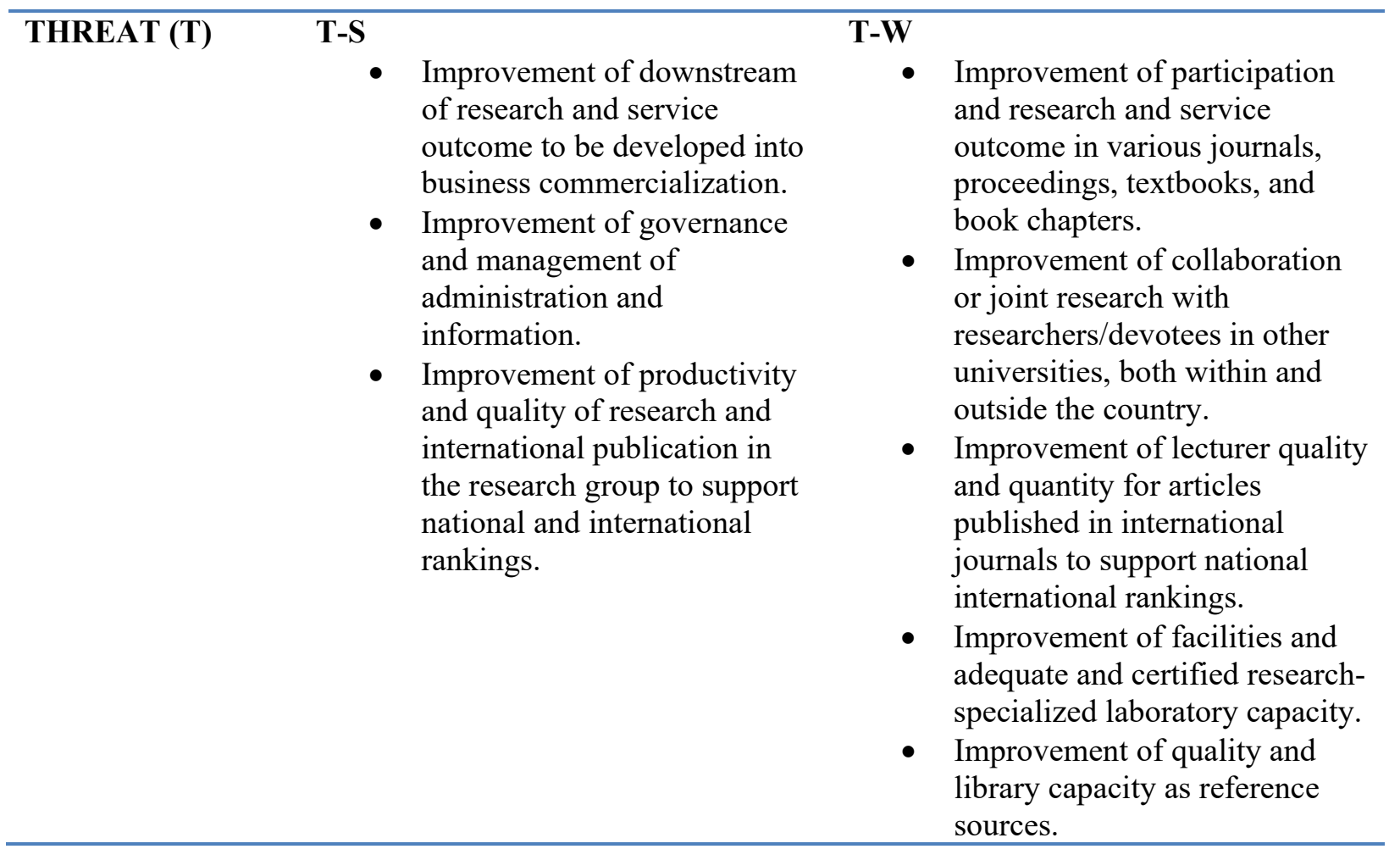

\section{CONCLUSION}

The SWOT analysis results provided benefits for the evaluation of the research group's performance and a breakthrough on improvement measures. The mapping of the research group condition showed a position in the second quadrant, which means the group required a diversification strategy. Based on the SWOT analysis results, the authors provided solutions to improve the performance of the research group which may help in determining the management policy in the faculty or the university level and changes in the management to be used in further studies.

\section{ACKNOWLEDGMENT}

The authors received a research grant from Hibah Penguatan dan Pengembangan Institusi of Sebelas Maret University, Indonesia with the contract number of 452/UN27.21/PN/2020 for the Faculty Coordinator of Research and Community Service (KPPMF) of the Faculty of Mathematics and Natural Sciences.

\section{REFERENCES}

Bowling, N.A., \& Hammond, G.D. (2008). A meta-analytic examination of the construct validity of the Michigan Organizational Assessment Questionnaire Job Satisfaction Subscale. Journal of Vocational Behavior, 73, 63-77.

Fardani, I., Agustina, I.H., \& Jauzi, F.A. (2020). Implementing SWOT analysis in engineering education. IOP Conf. Ser.: Mater. Sci. Eng., 830, 032066.

Forleo, M.B., \& Palmieri, N. (2019). The potential for developing educational farms: A SWOT analysis from a case study. The Journal of Agricultural Education and Extension, 25, 431-442.

Kaushik, A. (2018). SWOT analysis of MOOCs in library and information science domain. Library Hi Tech News. https://doi.org/10.1108/LHTN-08-2018-0048 
Kolomiets, A., Grinchenkov, D., \& Vodenko, K. (2019). PEST- and SWOT-analysis of university internationalization factors. J. Phys.: Conf. Ser., 1415, 012003.

LPPM UNS. (2020). Panduan Penelitian Dan Pengabdian Kepada Masyarakat, edisi VII; 2020, Lembaga Penelitian Dan Pengabdian Kepada Masyarakat. Universitas Sebelas Maret, Surakarta. Retrieved January 27, 2020, from https://lppm.uns.ac.id/id/2020/01/15/tawaran-proposal-barupenelitian-dan-pengabdian-kepada-masyarakat-p2m-sumber-dana-pnbp-uns-ta-2020/

Longhurst, G.J., Stone, D.M., Dulohery, K., Scully, D., Campbell, T., \& Smith, C.F. (2020). Strength, Weakness, Opportunity, Threat (SWOT) Analysis of the Adaptations to Anatomical Education in the United Kingdom and Republic of Ireland in Response to the Covid-19 Pandemic. Anatomical Sciences Education, 13, 301-311.

Mulyono, H., \& Saskia, R. (2020). Dataset on the effects of self-confidence, motivation and anxiety on Indonesian students' willingness to communicate in face-to-face and digital settings. Data in Brief, 31, 105774.

Permenristekdikti. (2016). Peraturan Menteri Riset, Teknologi, Dan Pendidikan Tinggi Republik Indonesia Nomor 42 Tahun 2016 tentang Pengukuran dan Penetapan Tingkat Kesiapterapan Teknologi. Retrieved August 8, 2020, from https://jdih.ristekbrin.go.id/produk-hukum/

Permenristekdikti. (2019). Peraturan Menteri Riset, Teknologi, Dan Pendidikan Tinggi Republik Indonesia Nomor 38 Tahun 2019 Tentang Prioritas Riset Nasional Tahun 2020-2024. Retrieved July 13, 2020, from https://jdih.ristekbrin.go.id/produk-hukum/

Zhu, C., \& Mugenyi, K.J. (2015). A SWOT analysis of the integration of e-learning at a university in Uganda and a university in Tanzania. Technology, Pedagogy and Education, 24, 1-19. 